\title{
CERITA RAKYAT BUSANG MAYUN DARI SUKU DAYAK KENYAH DI LONG LEJUH
}

\author{
Muhammad Thobroni \& Desem Soni
}

\author{
Universitas Borneo Tarakan \\ Jl. Amal Lama No 1, Pantai Amal, Tarakan, Kalimantan Utara, Indonesia \\ Pos-el: thobsatu@gmail.com
}

\begin{abstract}
Abstrack
Containing the value of culture folklore, education and moral values are beneficial. The dyaks of folklore Kenyah Lebu' Kulit is a form of long literary. This one comes with oral literary order of value and the contents of high quality and very useful to the development of regional literature. Folklore titled Busang Mayun the dyaks of Kenyah Lebu' Kulit in the village long Lejuh need to be identified because the stories so there have not been many locations the community, plus the influence of the development of technology advancement which gradually and quickly so that forgotten folklore. Folklore rarely never even told that masyarakaat dyaks Kenyah Lebu'Kulit in the long Lejuh called Busang Mayun no longer know and have known story their area. In this research writer will use the qualitative study, researchers collected data as usually by means of direct face to face and interacting with people in the research. In this research as a source of primary data were informants. Important data or information collected and examined in this research in the form of qualitative. The data more of words. In this research data obtained through oral information of the next speakers transcription into the story in writing. Folklore called Busang Mayun of dyaks Kenyah Lebu'Kulit containing culture elements. Cultural values or customs show anciently the community in the long lejuh obstinate in holding fast custom and culture. The community customs cultures or the dyaks of kenyah that existed in the village long lejuh still exist until now, Be seen from the inheritance to future generations, as forms of household appliances, a boat, machete, chopsticks, a spear, a shield, and others. The equipment that meant until now is still used by a community the dyaks of Kenyah Lebu'Kulit in the village long lejuh as supports the needs of the lives of the community.
\end{abstract}

\section{ABSTRAK}

Cerita rakyat mengandung nilai kebudayan, pendidikan maupun nilai-nilai moral yang bermanfaat. Cerita rakyat suku Dayak Kenyah Lebu' Kulit merupakan bentuk kesusastraan lama. Sastra lisan ini mempunyai tatanan nilai dan isi yang bermutu dan sangat bermanfaat bagi perkembangan sastra daerah. Cerita rakyat berjudul Busang Mayun suku Dayak Kenyah Lebu' Kulit di desa Long Lejuh perlu diidentifikasi karena cerita tersebut belum banyak di ketahui masyarakat, ditambah pengaruh perkembangan teknologi yang semakin cepat sehingga cerita rakyat terlupakan. Cerita rakyat jarang bahkan tidak pernah diceritakan sehingga masyarakaat suku Dayak Kenyah Lebu' Kulit di desa Long Lejuh berjudul Busang Mayun tidak lagi mengetahui dan mengenal cerita-cerita daerah mereka. Dalam penelitian ini penulis akan Muhammad Thobroni \& Desem Soni, Variasi Bahasa. (54-67) 
menggunakan penelitian kualitatif, karena biasanya peneliti mengumpulkan data dengan cara bertatap muka langsung dan berinteraksi dengan orang-orang di tempat penelitian. Dalam penelitian ini yang menjadi sumber data primer adalah informan. Data atau informasi penting yang dikumpulkan dan dikaji dalam penelitian ini berupa data kualitatif. Data yang ada lebih banyak berupa kata-kata. Data dalam penelitian ini diperoleh melalui informasi lisan dari para narasumber selanjutnya ditranskripsikan ke dalam cerita secara tertulis. Cerita rakyat berjudul Busang Mayun dari suku Dayak Kenyah Lebu' Kulit mengandung unsur budaya. Nilai budaya atau adat-istiadat menunjukan zaman dahulu masyarakat di desa Long Lejuh sangat memegang teguh adat-istiadatnya dan budaya. Budaya-budaya atau adat-istiadat masyarakat suku Dayak Kenyah yang ada di desa Long Lejuh masih ada sampai sekarang, ditunjukan dengan adanya warisan kepada generasi-generasi, seperti bentuk-bentuk peralatan rumah tangga, perahu, parang, sumpit, tombak, perisai, dan lain-lain. Peralatan-peralatan tersebut sampai sekarang masih digunakan oleh masyarakat suku Dayak Kenyah Lebu' Kulit di desa Long Lejuh sebagai penunjang kebutuhan hidup masyarakat.

Kata Kunci: cerita rakyat Busang Mayun, Dayak Kenyah Kalimantan Utara

\section{PENDAHULUAN}

Bangsa Indonesia kaya akan keragaman budaya. Keragaman budaya yang dimiliki masyarakat Indonesia dapat dilihat dari kekayaan sastra yang dimilikinya, termasuk cerita rakyat. Cerita rakyat di Indonesia jumlahnya sangat banyak dan masyarakat Indonesia itu terdiri dari berbagai etnik. Hal tersebut memberikan suatu gambaran yang nyata tentang keberagaman budaya Indonesia. Berbagai cerita rakyat yang tumbuh di Indonesia, memiliki kandungan nilai pendidikan yang tinggi. Nilai pendidikan ini banyak dijumpai dalam cerita-cerita rakyat karena selain mendidik sang anak cerita rakyat atau dongeng ini juga sebagai wahana pendekatan antara ibu dengan anak. Karena cara penyampaiannya melalui lisan maka sang pendongeng berinteraksi langsung dengan pendengar.

Sastra lisan mempunyai potensi dan peran sebagai kekayaan budaya. Dengan sastra lisan orang dapat mengetahui sejarah, pengalaman, pandangan hidup, adat istiadat, cita-cita dan berbagai kegiatan lain yang terdapat didalam cerita tersebut. Dalam sastra lisan ini sebenarnya tersirat kenyataan yang ada dalam masyarakat yang diceritakan sesuai pada kondisi masyarakat pada waktu itu. Maka

sangat perlu sastra lisan ini dikembangkan dan dilestarikan sebagai penyalur untuk diperkenalkan kepada masyarakat, dengan identifikasi ceritacerita rakyat lalu diangkat kembali lewat daya kreasi dan imajinasi ke dalam bentuk karya sastra. Agar cerita rakyat tidak berlalu begitu saja.

Setiap tahun cerita rakyat semakin berkurang. Hal tersebut terjadi karena memang cerita rakyat sekarang 
jarang atau bahkan tidak pernah lagi dikisahkan dalam lingkup keluarga bahkan masyarakat. Cerita rakyat semakin tidak dikenal lagi dikalangan masyarakat sekarang, ditambah lagi dengan aspek pembangunan dalam berbagai bidang dan berkembangnya ilmu pengetahuan dan teknologi, yang dipandang dapat mengurangi minat terhadap cerita rakyat suatu daerah. Cepat atau lambat kemajuan ini akan menimbulkan pergeseran nilai-nilai tertentu. Pesatnya kemajuan ilmu pengetahuan dan teknologi mempunyai pengaruh dalam mempercepat punahnya sastra lisan daerah. Hampir semua tayangan hiburan televisi serta isinya dianggap baik. Padahal, apabila dicermati tidak semua tayangan tersebut memiliki manfaat positif. Banyak di dalamnya terdapat unsur kekerasan, kenakalan, kebebasan, dan semacamnya. Sebagian besar tayangan tersebut disajikan kepada anak-anak tanpa melalui pengawasan orang tua. Hal seperti ini yang perlu dikhawatirkan, sehingga diperlukan adanya pengawasan yang cukup ketat dan hati-hati agar sisi negatif dalam tayangan-tayangan tersebut tidak terserap oleh anak-anak. Masalah seperti inilah yang membuat cerita rakyat seakan terlupakan.

Cerita rakyat sebagai salah satu warisan budaya bangsa, menyimpan berbagai misteri berupa sejarah dan nilai-nilai masa lalu bangsa yang harus digali dan diperhitungkan eksistensinya. Cerita rakyat juga erat hubungannya dengan pencerita atau pendongeng. Nyaris di setiap daerah pendongeng itu hilang atau sedikit sekali jumlahnya. Hal ini dikarenakan para Pendongeng meninggal dunia atau pada sebagaian masyarakat sendiri tidak memiliki perhatian lebih pada cerita-cerita rakyat yang dimiliki daerah itu. Penceritaan dianggap sebagai tugas dan kewajiban serta tanggung jawab penelitian, karena kenyataannya para pencerita tidak mendokumentasikan cerita-cerita itu menjadi buku. Yang mana buku-buku itu bisa dibaca atau diwariskan pada generasi penerusnya. Hal itulah yang menjadi suatu masalah penting yang harus dilakukan untuk mendokumentasikan cerita-cerita tersebut. Maka sangat penting diteliti cerita rakyat yang masih banyak terdapat dimasyarakat pedesaan. jika tidak segera diteliti dan dibukukan maka cerita-cerita rakyat yang ada akan punah.

Cerita rakyat banyak mengandung nilai-nilai kebudayan, pendidikan maupun nilai-nilai moral yang bermanfaat. Di setiap daerah pasti mempunyai cerita rakyat, Begitu juga dengan Cerita rakyat yang ada disuku Dayak Kenyah Lebu' Kulit adalah merupakan salah satu bentuk kesusastraan lama dimana masyarakat suku Dayak Kenyah Lebu Kulit telah mengenal sastra lisan. Sastra lisan ini mempunyai tatanan nilai dan isi yang bermutu dan sangat bermanfaat bagi perkembangan sastra daerah. Ceritacerita rakyat suku Dayak Kenyah Lebu' Kulit di desa Long Lejuh perlu diidentifikasi karena cerita-cerita itu belum banyak diketahui dikalangan masyarakat luas belum lagi pengaruh perkembangan teknologi yang semakin maju sehingga cerita-cerita rakyat 
daerah sering terlupakan bahkan diabaikan. Cerita-cerita rakyat ini jarang bahkan tidak pernah diceritakan sehingga masyarakaat suku Dayak Kenyah Lebu' Kulit di desa Long Lejuh, tidak lagi mengetahui dan mengenal cerita-cerita di daerah mereka. Cerita rakyat suku Dayak Kenyah Lebu' Kulit telah lama dikenal, terbukti dengan adanya cerita-cerita yang tersebar luas masyarakat suku Dayak Kenya Lebu' Kulit khususnya masyarakat yang ada di desa Long Lejuh.

Masyarakat suku Dayak Kenyah Lebu' Kulit desa Long Lejuh ini terletak di Kecamatan Peso Kabupaten Bulungan Kalimantan Utara. Letak desa Long Lejuh sangat jauh dari perkotaan dan transportasi masih terbilang sulit karena jalan menuju ke desa Long Lejuh hanya melalui sungai, sungai yang disebut dengan sungai Kayan. Desa Long Lejuh letaknya di hulu sungai Kayan. Masyarakat yang ada di desa Long Lejuh ini secara tidak langsung telah lama mengenal sastra, secara khususnya sastra lisan. Masyarakat suku Dayak Kenyah Lebu' Kulit di desa Long Lejuh terdapat banyak ceritacerita rakyat yang memiliki nilai-nilai moral, pendidikan, dan nilai budaya yang tinggi, jika tidak diteliti dan tidak didokumentasikan maka cerita-cerita yang ada akan punah dan hilang. Cerita-cerita rakyat tidak lepas dari yang namanya pendongeng. Pendongeng biasanya identik dengan orang-orang sudah lanjut usia. Pendongeng ini sangat penting perannya dalam pelestarian cerita-cerita rakyat, karena jika cerita-cerita yang dimiliki oleh sipendongeng ini tidak didokumentasikan maka cerita-cerita akan punah dan berlalu begitu saja, lantaran faktor usia yang semakin tua.

Cerita-cerita rakyat suku Dayak Kenyah Lebu' Kulit yang ada di desa Long Lejuh ini sangat penting untuk digali dan identifikasi lebih dalam dan mengetahui makna, fungsi, dan nilainilai yang terdapat pada cerita-cerita, melalui penelitian terhadap informaninforman yang mengenal dan mengetahui cerita-cerita yang ada. Melalui penelitian ini maka akan menghasilkan banyak cerita-cerita rakyat yang akan didokumentasikan lalu di kalisifikasikan, sehingga ceritacerita rakyat masyarakat suku Dayak Kenyah Lebu' Kulit yang ada di desa Long Lejuh tidak hilang, dan generasigenerasi muda juga mengetaui ceritacerita melalui pendokumentasian seperti buku maupun rekaman. Peneliti tertarik mengkaji sosial budaya ceritacerita masyarakat suku Dayak Kenyah Lebu' Kulit yang ada di desa Long Lejuh, Long Peso, Kabupaten Bulungan, Kalimantan Utara.

Menurut Endraswara (2011: 151) sastra lisan adalah karya yang penyebarannya disampaikan dari mulut ke mulut secara turun-temurun. Menurut Amir (2013: 19) sastra lisan penting dikaji karena beberapa alasan. Alasan yang pertama, ia ada dan terus hidup ditengah masyarakat, tidak saja dalam masyarakat Indonesia tetapi juga di banyak negara lain di dunia. Sastra lisan itu hidup pada masyarakat pertamanya, yaitu masyarakat yang melahirkannya dan menghidupkannya, di daerah kelahiran, di kampung asal. Menurut Okke K.S Zaimar dalam 
Pudentia (2008: 320) sastra lisan adalah semua cerita yang sejak awalnya disampaikan secara lisan, tidak ada naskah tertulis yang dapat dijadikan pegangan.

Dari pendapat para ahli maka dapat disimpulkan dalam cerita rakyat Dayak kenyah Lebu Kulit, termasuk dalam sastra lisan karena dalam penyebarannya melalui mulut ke mulut, pengarangnya tidak diketahui, dan tidak dalam bentuk tulisan. Maka dinilai sangat penting untuk diteliti agar sastra lisan seperti cerita rakyat yang ada di desa Long Lejuh, yang belum banyak diketahui oleh masyarakat dapat diidentifikasi, didokumentasikan, dan dianalisis nillai-nilai yang terkandung didalamnya agar masyarakat dapat mengetahui dengan benar apa dan bagaimana sebenarnya fungsi dan makna-makna yang terkandung dalam sebuah cerita rakyat. Agar masyarakat tidak hanya mendengar dan melupakannya begitu saja, jika masyarakat di desa Long Lejuh mengerti akan pentingnya sastra lisan itu maka akan terdorong untuk melestarikan semua yang berbentu sastra lisan, salah satunya adalah cerita rakyat. Maka harus ada pelestarian dengan mengidentifikasi cerita-cerita yang ada, dan didokumentasikan lalu dianalisis nilai- nilai yang terdapat didalam cerita-cerita tersebut, agar sastra lisan di desa Long Lejuh tidak punah.

Menurut Danandjaja (2007: 1) kata foklor adalah pengIndonesian kata Inggris foklore. Kata itu adalah majemuk, yang berasal dari dua kata dasar folk dan lore. Foklor mengandung arti nilai budaya yang dapat dimanfaatkan sebagai sumber pendidikan. Nilai budaya yang terkandung dalam genre foklor merupakan pesan-pesan sebagai sumber pengetahuan atau pendidikan bagi generasi penerus. (Endraswara 2013: 17). Namun yang lebih penting lagi adalah mereka bahwa mereka telah memiliki suatu tradisi, yakni kebudayaan yang telah mereka warisi turun-temurun, sedikitnya dua generasi yang dapat mereka akui sebagai milik bersamanya. Disamping itu yang paling penting adalah bahwa mereka sadar akan identitas kelompok mereka sendiri. (Dundes dalam Danandjaja 2007: 1). Jadi folk adalah sinonim dengan kolektid, yang juga memiliki ciri-ciri pengenal fisik atau kebudayaan yang sama.

Definisi foklor secara keseluruhan adalah sebagai kebudayaan suatu kolektif, yang tersebar dan diwariskan turun-temurun diantara kolektif macam apa saja, secara tradisional dalam versi yang berbeda baik dalam bentuk lisan maupun contoh yang disertai gerak isyarat atau alat pembantu pengingat. (Danandjaja 2007: 2). Dari berbagai pendapat menurut beberapa ahli maka dapat disimpulkan bahwa foklor banyak membicarakan tentang tradisi-tradisi maupun kebudayaan lama yang proses penyabarannya melalui lisan, yaitu dari mulut ke mulut, yang setiap daerah memiliki ciri khas yang berbeda-beda sesuai dengan budaya setempat.

Menurut Danandjaja (2007: 50) dari semua bentuk genre foklor, yang paling banyak diteliti para ahli foklor adalah cerita prosa rakyat. Cerita rakyat 
menjadi bagian dari kekayaan budaya dan sejarah yang dimiliki setiap bangsa. Jika digali dengan sungguh-sungguh, negeri kita sebenarnya berlimpah cerita rakyat yang menarik. Cerita rakyat dapat diartikan sebagai ekspresi budaya suatu masyarakat melalui bahasa tutur yang berhubungan langsung dengan berbagai aspek budaya dan susunan nilai sosial masyarakat tersebut. Cerita rakyat diwariskan secara turunmenurun dari satu generasi ke generasi berikutnya secara lisan

Cerita rakyat adalah cerita yang berkembang dan hidup di kalangan masyarakat. Cerita rakyat berkembang secara turun-temurun dan disampaikan secara lisan. Oleh karena itulah, cerita rakyat sering pula disebut sebagai sastra lisan. Pada umumnya, cerita rakyat bersifat anonim atau pengarangnnya tidak dikenal. Cerita rakyat ini termasuk dalam cerita prosa rakyat yang dibahas dalam foklor.

Suku Kenyah adalah suku Dayak yang termasuk rumpun Kenyah-KayanBahau yang berasal dari dataran tinggi Usun Apau, daerah Baram, Sarawak. Dari wilayah tersebut suku Kenyah memasuki Kabupaten Malinau, Kalimantan Timur melalui sungai Iwan di Sarawak terpecah dua sebagian menuju daerah Apau Kayan yang sebelumnya ditempati suku Kayan dan sebagian yang lainnya menuju daerah Bahau. Pergerakan suku ini menuju ke hilir akhirnya sampai ke daerah Mahakam dan akhirnya sebagian menetap di Kampung Pampang Samarinda Utara, Samarinda. Sebagian lagi bergerak ke hilir menuju Tanjung Palas. Suku Kenyah terbagi menjadi
Kenyah Dataran Rendah dan Kenyah Dataran Tinggi /Usun Apau Kenyah. Seni budaya suku Kenyah sangat halus dan menarik, sehingga ragam seni hias banyak dipakai pada bangunanbangunan di Kalimantan Timur. Bukan Saja terdiri pada seni ukiran tetapi tarian dan juga cara hidup.

Dayak Kenyah terdiri dari beberapa sub suku lagi seperti:

1. Kenyah Bakung

2. Kenyah Lepok Bam

3. Kenyah Lepok Jalan

4. Kenyah Lepok Tau'

5. Kenyah Lepok Tepu

6. Kenyah Lepok Ke

7. Kenyah Umag Tukung

8. Kenyah Umag Maut

9. Kenyah Lepok Timei

10. Kenyah Lepok Kulit

11. Kenyah Umag Lasan

12. Kenyah Umag Lung

13. Kenyah Uma Kelep

Dari beberapa penelitian yang dilakukan oleh para peneliti sejarah dan anthropolog, bahwa suku Dayak Kayan dan suku Dayak Kenyah termasuk suku dayak tertua di Kalimantan, yang telah menghuni pulau Kalimantan sejak ribuan tahun Sebelum Masehi, yang diduga bermigrasi dari daerah selatan Cina. Suku Dayak adalah suku asli Kalimantan yang hidup berkelompok yang tinggal dipedalaman, di gunung, dan sebagainya. Kata Dayak itu sendiri sebenarnya diberikan oleh orang-orang Melayu yang datang ke Kalimantan. Orang-orang Dayak sendiri sebenarnya keberatan memakai nama Dayak, sebab lebih diartikan agak negatif. Padahal, semboyan orang Dayak adalah "Menteng Ueh Mamut", yang berarti 
seseorang yang memiliki kekuatan gagah berani, serta tidak kenal menyerah atau pantang mundur. Bagi kebanyakan orang khususnya yang tinggal di Kalimantan Timur, kata atau suku Dayak mungkin sudah cukup dikenal (Wikipedia, 2013). Suku Dayak terdiri dari berbagai sub-sub suku yang salah satu dari sub-sub suku itu adalah Dayak Kenyah yang ada di desa Long Lejuh Kecamatan Peso Kabupaten Bulungan Kalimantan Utara.

\section{METODE PENELITIAN}

Dalam penelitian ini penulis akan menggunakan penelitian kualitatif, karena biasanya peneliti mengumpulkan data dengan cara bertatap muka langsung dan berinteraksi dengan orang-orang di tempat penelitian.

Menurut Moleong (2007: 168) kedudukan peneliti dalam penelitian kualitatif cukup rumit, ia sekaligus merupakan perencana, pelaksana pengumpulan data, analisis, penafsiran data, dan pada akhirnya ia menjadi pelapor hasil penelitiannya. Sugiyono (2014: 8) dalam penelitian kualitatif instrumennya adalah orang atau human instrument, yaitu peneliti itu sendiri. Untuk dapat menjadi insrument, maka peneliti harus memiliki bekal teori dan wawasan yang luas, sehingga mampu bertanya, menganalisis, memotret, dan mengkonstruksi situasi sosial yang diteliti menjadi lebih jelas dan bermakna. Penelitian kualitatif sebagai human instrument, berfungsi menetapkan fokus penelitian, memilih informan sebagai sumber data, melakukan pengumpulan data, menilai kualitas data, analisis data, menafsirkan data dan membuat kesimpulan atas temuannya (Sugiyono 2014: 222).

Sesuai dengan pendapat diatas menjadi landasan penulis dalam melakukan penelitian dengan menggunakan metode kualitatif, dan informan sebagai sumber data dalam penelitian tentang cerita-cerita Dayak Kenyah Lebu' Kulit yang ada di desa Long Lejuh Kabupaten Bulungan setelah itu menganalisis nilai-nilai yang terdapat didalamnya.

Data merupakan unsur penting dalam penelitian. Tanpa adanya data penelitian tidak bisa dilakukan. Menurut Arikunto (2010: 172) sumber data dalam penelitian adalah subjek darimana data dapat diperoleh. Sumber data dalam penelitian ini menggunakan sumber data Primer karena sumber data yang langsung memberikan data kepada pengumpul data. Data yang diambil mengenai hal-hal yang diteliti berdasarkan wawancara dan observasi yang diambil pada saat penelitian. Menurut Lofland dalam Moeloeng (2009: 157), sumber data utama dalam penelitian kualitatif adalah kata-kata, dan tindakan selebihnya adalah data tambahan seperti dokumen dan lainlain. Kata-kata dan tindakan orangorang yang diamati atau diwawancarai merupakan sumber data utama. Sumber data utama dicatat melalui catatan tertulis atau melalui perekaman video/ audio tapes, pengambilan foto, atau film (Moleong 2009: 157).

Dalam penelitian ini yang menjadi sumber data primer adalah informan. Data atau informasi penting yang dikumpulkan dan dikaji dalam 
penelitian ini berupa data kualitatif. Data yang ada lebih banyak berupa kata-kata. Data dalam penelitian ini diperoleh melalui informasi lisan dari para narasumber selanjutnya ditranskripsikan ke dalam cerita secara tertulis. Sumber data, Data penelitian tentang Cerita Rakyat Dayak Kenyah Lebu Kulit digali melalui beberapa sumber, yaitu informan yang bisa memberikan informasi secara lengkap dan akurat seperti ketua adat, atau orang-orang tua yang dihormati di desa Long Lejuh Kabupaten Bulungan. Adapun kriteria usia informan adalah, 50 tahun ke atas, karena informan yang mengetahui cerita-cerita yang ada di desa Long Lejuh ini adalah orang-orang yang usianya telah tua dan benar-benar penduduk asli desa Long Lejuh.

\section{HASIL DAN PEMBAHASAN}

Kajian terhadap cerita rakyat berjudul Busang Mayun dari Suku Kenyah di Long Lejuh, Long Peso, Kabupaten Bulungan di Kalimantan Utara, Indonesia, dapat dijabarkan berikut ini.

\section{Isi cerita}

Pada jaman dahulu yaitu tepatnya di hulu sungai kayan, hiduplah seorang yang paling dihormati dan disegani oleh masyarakatnya yaitu disebut dengan "Lai Bara" pada waktu kepemimpinannya masyarakat sangat sejahtera dan hidup damai, segala kebutuhan dan keperluan dapat terpenuhi sehingga masyarakatnya tidak kesusahan, dibawah kepemimpinannya. Mereka selalu bergotong royong dalam membangun desa mereka. Lai Bara sangat perduli dengan masyarakatnya segala keputusan dan perintahnya sangat dihargai, karena semuanya untuk kepentingan orang banyak. Itu lah yang membuat orang-orang senang dengan Lai Bara. Setelah sekian lama ia memimpin ia memiliki dua anak lakilaki. Mereka tumbuh dewasa dan akan menjadi penerus kejayaan ayahnya.

Tiba suatu hari Lai Bara mengalami sakit, sekian lama ia menderita sakit lalu meninggal dan Lai Bara belum sempat memberikan hak atau memilih diantara kedua anaknya yang akan memimpin masyarakatnya. Pada waktu mereka ingin menguburkan mayat Lai Bara terjadi banjir, sehingga membuat mereka kesulitan untuk melakukan penguburan. Lalu masyarakat membuat peti dari batu dan menyimpan mayat Lai Bara di dalam peti batu itu.

Sekian lama masyarakat tidak memiliki pemimpin, sehingga kedua anaknya membuat kubu tersendiri akhhirnya masyarakat terbagi menjadi dua kubu sehingga membuat masyarakatnya tidak memiliki hidup yang damai. Akhirnya timbul pemikiran mereka untuk menguasai dan ingin menjadi pemimpin, sehingga membuat mereka bersaing. Karena melihat kedua anak dari Lai Bara ini ingin menjadi pemimpin, sehingga membuat masyarakat ingin membuat mereka bermusuhan, mulailah mereka menghasut salah satu dari mereka, dibuatlah cerita rekayasa dan menjelekkan satu sama lain, sehingga membuat mereka menjadi marah dan berseteru. Akhirnya mereka 
memutuskan untuk bertarung, menentukan siapa yang pantas untuk memimpin masyarakat menggantikan ayah mereka. Mereka pun bertarung dengan hebatnya sehingga salah satu dari mereka terluka parah. Pada saat itu lah mereka berbicara, "mengapa engkau menjelek-jelekkan saya kata yang satu", saudaranya juga berkata demikian. "Saya tidak pernah mengatakan seperti yang kamu katakan" kata anak pertama dari Lai Bara. Setelah mereka berbicara akhirnya mereka menemukan jalan keluar, ternyata ada yang sengaja menghasut mereka. Setelah kejadian itu hubungan mereka tidak baik. Sehingga salah satu memutuskan untuk pindah, mencari daereah lain. "Kita tidak bisa hidup seperti ini, salah satu dari kita harus mencari daerah lain" dan saya harus mengalah demi kebaikan dan demi ketenraman masyarakat. Kata anak kedua dari Lai Bara. Akhirnya kelompok dari anak kedua Lai Bara memutuskan untuk pindah dan mereka membawa peti Lai Bara. Mereka menyusuri sungai untuk mencari daerah tempat tinggal mereka dengan menggunakan perahu panjang. Sampailah mereka disuatu tempat yang dinamakan "Lung Blangan" . Mereka menetap dan anak kedua dari Lai Bara menjadi pemimpin mereka dan mengaja mereka bergotong royong membuat pemukiman di daerah itu.

Pada suatu malam mereka di timpa musibah banjir besar menimpa tempat pemukiman mereka. Anak kedua Lai Bara, memegang dayung dan ingin mencari perahu untuk menyelamatkan diri dan peti ayahnya. Lalu ia menyeret dayung itu, dan berlari ingin menyelamatkan peti ayahnya.
Melihat banjir itu semakin naik ia pun mulai panik dan berkata "Hentikanlah banjir ini ya dewa air". Karena kesaktiannya ia tidak sadar bahwa kepanikannya telah mengeluarkan kekuatnnya dan garis dari dayung yang diseret itu terpisah dan membentuk suatu pulau, lalu pulau itu hanyut karena banjir. Dan peti Lai Bara pun Hanyut terbawa banjir. Setelah kejadian itulah anak Lai Bara sangat marah kepada masyarakatnya karena satupun tidak ada yang menyelamatkan peti ayahnya lantaran sibuk menyelamatkan diri masing-masing. Pada waktu itu ia pun bersumpah, bahwa, "Sampai disinilah kita melihat jasat ayah saya dan akhirnya kita tidak akan pernah melihatnya lagi, dan saya bersumpah demi Bungan Malan, kita tidak akan bisa pergi ke hulu sungai melewati Pulau ini. Lalu pulau yang tidak sengaja dibuat oleh anak dari Lai Bara itu di namakan dengan "Busang Mayun" (Pulau Hanyut) untuk menandakan bahwa peti ayahnya telah hanyut didaerah itu.

\section{Nilai Moral}

"Lai Bara sangat perduli dengan masyarakatnya segala keputusan dan perintahnya sangat dihargai, karena semuanya untuk kepentingan orang banyak. Itu lah yang membuat orang-orang senang dengan Lai Bara".

Kutipan diatas menunjukan dalam cerita Busang Mayun terdapat nilai moral dari tokoh Lai Bara yang menujukan kewibawaan seorang pemimpin dengan hati yang sangat baik dan ramah sehingga masyarakatnya sangat senang dengan segala keputusan 
dan perintahnya, karena semuanya itu untuk kepentingan orang banyak bukan untuk kepentingan diri sendiri. Pada waktu itu kehidupan masyarakat yang dipimpin oleh Lai Bara sangat sejahtera baik dari segi kebutuhan hidup dan dalam pembangunan berjalan denga baik, dikarenakan masyarakatnya sangat patuh akan perintah dari pemimpinnya.

"Kita tidak bisa hidup seperti ini, salah satu dari kita harus mencari daerah lain" dan saya harus mengalah demi kebaikan dan demi ketenraman masyarakat". Kata anak kedua dari Lai Bara. Kutipan tersebut mengandung nilai moral yang menunjukan rasa besar hati seorang adik kepada kakaknya yang tidak ingin bersaing merebut jabatan dan lebih mementingkan kesejahteraan masyarakatnya, sehingga ia mengabaikan kekerasan hatinya dan lebih memilih mengalah demi kebaikan untuk masyarakatnya.

"Anak kedua Lai Bara, memegang dayung dan ingin mencari perahu untuk menyelamatkan diri dan peti ayahnya. Lalu ia menyeret dayung itu, dan berlari ingin menyelamatkan peti ayahnya". Kutipan di atas menjelaskan hati seorang anak yang sangat mencintai ayahnya, sehingga dalam kutipan menjelaskan bagaimana anak kedua dari Lai Bara memegang dayung dan mencari perahu untuk segera menyelamatkan petih ayahnya, anak kedua dari Lai Bara ini sangat panik sehingga membuat ia berlari untuk menyelamatkan peti ayahnya dimana pada waktu itu pemukiman mereka dilanda banjir yang datang dengan tiba-tiba.

\section{Nilai Adat-istiadat}

"Pada waktu kepemimpinannya masyarakat sangat sejahtera dan hidup damai, segala kebutuhan dan keperluan dapat terpenuhi sehingga masyarakatnya tidak kesusahan, dibawah kepemimpinannya. Mereka selalu bergotong royong dalam membangun desa mereka". Kutipan tersebut menunjukan masyarakat suku Dayak Kenyah pada waktu itu sudah mengenal budaya gotong royong, gotong royong dalam membangun, baik itu dalam membangun rumah, dan hal-hal yang melibatkan orang banyak. Masyarakat suku Dayak Kenyah dalam bermasyarakat sangat membutuhkan sosok pemimpin yang bisa memimpin dan mengayomi masyarakatnya, ditunjukan dalam cerita bahwa sosok Lai Bara sangat disenangi oleh masyarakatnya karena kepemimpinannya yang bagus dan selalu mengutamakan orang banyak tidak mementingkan dirinya sendiri.

"Lalu masyarakat membuat peti dari batu dan menyimpan mayat Lai Bara di dalam peti batu itu". Kutipan tersebut menunjukkan bahwa Masyarakat suku Dayak Kenyah pada zaman dahulu jika memakamkan orang yang telah meninggal dunia tidak dikuburkan seperti biasanya melainkan mayat itu disimpan dalam sebuah peti yang terbuat dari kayu, yaitu sebuah batang kayu yang dilubangi lalu mayat didiamkan didalam lubang kayu itu, lalu petinya disimpan diatas pohon kayu yang besar. Jika mayat telah membusuk dan telah menjadi tulang, tulangnya diambil oleh keluarganya dan dikuburkan. Dalam cerita Busang 
Mayun ini, peti Lai Bara dibuat dari batu itu sebagai penghormatan masyarakat kepada Lai Bara karena kepemimpinannya dalam memimpin masyarakat sangat di senangi dan masyarakat sangat menghormati sosok seorang Lai Bara yang sangat berjasa dan yang telah lama memimpin masyarakat di tempat itu. Masyarakat sangat kehilangan sosok seorang pemimpin seperti Lai Bara sehingga mereka memutuskan untuk mengenangnya dengan membuat peti yang terbuat dari batu, supaya tidak mudah lapuk.

"Mereka menyusuri sungai untuk mencari daerah tempat tinggal mereka dengan menggunakan perahu panjang". Adat istiadat maupun budaya masyarakat suku Dayak Kenyah pada zaman dahulu selalu menggunakan perahu panjang jika mereka berpergian ketempat-tempat yang jauh dan membawa orang banyak. Perahu panjang ini jika disebut dalam bahasa Dayak Kenyah Lebu' Kulit adalah "Alut Pasa". Perahu panjang ini adalah alat transportasi untuk berpergian kedaerahdaerah yang jauh, bentuknya perahu panjang ini panjang dan kedua ujung perahu lancip, memuat sekitar dua puluh orang. Pada waktu itu orangorang hanya menggunakan dayung, hanya mengandalkan kekuatan tangan untuk mendorong perahu dan mengarahkan perahu tersebut.

"Mereka menetap dan anak kedua dari Lai Bara menjadi pemimpin mereka dan mereka bergotong royong membuat pemukiman di daerah itu". Adat-istiadat masyarakat suku Dayak Kenyah jika misalnya anak yang lahir dari pemimpin atau disebut sebagai kepala suku sangat dihormati dan memiliki kelas yang tinggi berbeda dengan masyarakat biasa. Jika ayahnya telah meninggal makan jabatan ayahnya tersebut akan diambil atau diteruskan oleh anaknya. Begitu juga dengan anak dari Lai Bara yang otomatis diangkat sebagai pemimpin masyarakatnya karena dilihat dari riwayat keluarganya.

"Pada suatu malam mereka di timpa musibah banjir besar menimpa tempat pemukiman mereka. Anak kedua Lai Bara, memegang dayung dan ingin mencari perahu untuk menyelamatkan diri dan peti ayahnya". Adat-istiadat suku Dayak Kenyah, jika terjadi bencana seperti banjir, maka setiap orang wajib memegang dayung karena setiap rumah wajib memiliki dayung dan perahu. Dayung dalam bahasa Dayak Kenyah Lebu' Kulit adalah Besai. Dayung atau Besai tersebut disimpan didapur agar lebih muda untuk mengambil jika terjadi banjir. Jika terjadi banjir secara tiba-tiba maka setiap orang mengambil dayung dan segera menuju perahunya masing-masing.

\section{Nilai Agama}

"Melihat banjir itu semakin naik ia pun mulai panik dan berkata "Hentikanlah banjir ini ya dewa air". Kutipan tersebut menunjukan zaman dulu telah mengenal kepercayaan, kepercayaan anak kedua dari Lai Bara dalam cerita Busang Mayun ini mempercayaai akan adanya dewa dalam cerita menunjukan bahwa ia meminta pertolongan kepada dewa, sedangkan anak kedua dari Lai Bara ini memiliki kekuatan yang telah diwariskan dari keturunan ayahnya, 
meskipun ia memiliki kekuatan tetapi ia tetap meminta pertolongan kepada dewa air, menunjukan bahwa ia lebih mempercayai dewa air, dan dewa air itulah yang memberikan banjir itu itulah ia tidak bisa melawan dewa. Dan hanya meminta pertolongan kepada dewa air. Budaya tersebut menunjukan manusia meskipun memiliki kekuatan yang luar biasa masih ada yang bisa melebihi kekuatannya, maka jangan selalu mengandalkan kekuatan yang ada pada diri kita karena masih ada yang lebih berkuasa yaitu Tuhan Yang Maha Esa yang menciptakan seisi dunia ini.

"Sampai disinilah kita melihat jasat ayah saya dan akhirnya kita tidak akan pernah melihatnya lagi, dan saya bersumpah demi Bungan Malan, kita tidak akan bisa pergi ke hulu sungai melewati Pulau ini". Kutipan cerita Busang Mayun menunjukan kepercayaan masyarakat mempercayai adanya yang lebih berkuasa, dewa atau yang dipercaya oleh masyarakat dalam cerita Buasang Mayun adalah percaya kepada dewa Bungan Malan, Bungan Malan dipercaya adalah dewa yang dipercaya bisa melindungi masyarakat suku Dayak Kenyah, memberikan rejeki dan sangat berkuasa di alam semesta. Dalam kutipan menunjukan bahwa anak kedua dari Lai Bara menggunakan nama dewa Bungan Malan dalam bersumpah, menunjukan bahwa ia sangat meninggikan dan mengandalkan dewa Bungan Malan agar sumpahnya itu dapat benar-benar terjadi.

\section{Nilai Sosial}

Nilai sosial dalam cerita Busang Mayun menunjukan suku dayak telah mengenal hidup bersosial dengan sesama, ditunjukan dengan adanya aktivitas-aktivitas masyarakat secara bersama-sama baik dalam membangun juga dalam berkomunikasi terhadap satu dengan yang lain. Kutipan-kutipan yang menunjukan adanya nilai sosial dalam cerita Busang Mayun adalah sebagai berikut. "Mereka selalu bergotong royong dalam membangun desa mereka. Lai Bara sangat perduli dengan masyarakatnya segala keputusan dan perintahnya sangat dihargai, karena semuanya untuk kepentingan orang banyak. Itu lah yang membuat orang-orang senang dengan Lai Bara". Kutipan tersebut menunjukan cerita Busang Mayun, masyarakat telah mengenal budaya gotong royong, budaya gotong royong dimasyarakat suku Dayak Kenyah telah ada, dan terus berjalan dari waktu-kewaktu gotong royong dalam membangun, dan berpartisipasi dalam segala hal yang melibatkan banyak orang. Dalam cerita Busang Mayun menjelaskan bahwa kepemimpinan seorang Lai Bara membuat masyarakatnya sangat antusias dalam bergotong royong, karena masyarakat sangat senang dengan kepemimpinan dari Lai Bara, ia memimpin masyarakat dengan baik dan selalu mementingkan kepentingan orang banyak dan tidak mementingkan dirinya sendiri.

"Lalu masyarakat membuat peti dari batu dan menyimpan mayat Lai Bara di dalam peti batu itu". Kutipan tersebut menunjukan bahwa masyarakat bersama-sama untuk membuat peti untuk pemimpin mereka yaitu Lai Bara, nilai sosial yang tinggi dimiliki oleh masyarakat dalam cerita Busang Mayun, 
sehingga mereka dengan suka rela membuat peti untuk Lai Bara peti ini bukan peti biasa, yang biasanya petipeti untuk orang mati hanya dibuat menggunakan bahan kayu, tetapi peti Lai Bara terbuat dari batu, menunjukan rasa hormat mereka terhadap Lai Bara.

Dengan bekerjasama mereka dapat membuat peti yang terbuat dari batu, jika dibandingkan dengan sekarang orang-orang tidak lagi seperti jaman dahulu, rasa penghormatan masyarakat terhadap pemimpin sangatlah besar.

"Mereka menetap dan anak kedua dari Lai Bara menjadi pemimpin mereka dan mengaja mereka bergotong royong membuat pemukiman di daerah itu". Cerita Busang Mayun nilai-nilai sosial yang mengedepankan nilai sosial masyarakat seperti bergotong royong dan lain-lain, budaya bergotong royong sangat diutamakan oleh masyarakat. Dalam cerita Busang Mayun pada saat anak kedua dari Lai Bara membawa masyarakatnya pindah dan ia menjadi pemimpin lalu membawa mereka untuk bergotong royong untuk membangun permukiman di daerah tersebut. Sehingga ia diangkat menjadi pemimpin dan mewariskan sikap dari ayahnya. Nilai sosial yang ditunjukan oleh anak dari Lai Bara begitu persis seperti ayahnya, nilai-nilai sosial seperti inilah yang diingini oleh masyarakat, dimana seorang pemimpin yang dapat merangkul dan menjadi panutan dalam masyarakat.

\section{SIMPULAN}

Dari pembahasan di atas dapat disampaikan bahwa dalam cerita rakyat suku Dayak Kenyah Lebu' Kulit, terdapat banyak sekali unsur-unsur budaya yang terkandung didalamnya. Nilai-nilai budaya atau adat-istiadat lebih dominan lebih banyak dari nilainilai yang lain. Hal ini menunjukan bahwa pada zaman dahulu masyarakat di desa Long Lejuh sangat memegang teguh akan adat-istiadatnya dan budaya, yang dijalani oleh masyarakat pada waktu itu. Budaya-budaya atau adat-istiadat masyarakat suku Dayak Kenyah yang ada di desa Long Lejuh ini masih ada sampai sekarang, ditunjukan dengan adanya warisan-warisan yang diberikan kepada generasi-generasi, seperti bentuk-bentuk peralatan pada zaman itu, perahu, parang, sumpit, tombak, perisai, dan lain-lain. Peralatan-peralatan tersebut sampai sekarang masih digunakan oleh masyarakat suku Dayak Kenyah Lebu' Kulit di desa Long Lejuh sebagai penunjuang kebutuhan hidup masyarakat.

\section{DAFTAR PUSTAKA}

Amir, Edriyati. 2013. Sastra Lisan Indonesia. Yogyakarta: Penerbit Andi

Arikunto, Suharsimi. 2010. Prosedur Penelitian : Suatu Pendekatan Praktis, edisi revisi 2010. Jakarta : Rineka Cipta

Endraswara, Suwardi. 2011. Metodologi Penelitian Sastra Bandingan. Jakarta: Bukupop 
Danandjaya, James. 2002. Folklor Indonesia ilmu gosip dongeng dan lainlain. Jakarta: Pustaka Utama Garafiti

Danandjaya, James. "Pendekatan Folklor dalam Penelitian Bahanbahan Tradisi Lisan" dalam Pudentia. Ed. 1998. Metodologi Kajian Sastra Lisan. Jakarta: Yayasan Obor Indonesia

Moleong. Lexy J. 2007. Metodologi Penelitian Kualitatif. Bandung: Rosda Karya

Sugiyono. 2014. Metode Penelitian Kuantitatif, Kualitatif, dan $R \quad \mathcal{E} D$. Bandung: Alfabeta 